Ethos: Jurnal Penelitian dan Pengabdian kepada Masyarakat, Vol 8, No.2, Juni 2020: 242-247

\title{
Pengaruh Kemudahan, Kebutuhan, Kemampuan, Minat terhadap Persepsi GuRU DALAM MENGgunAKan APLiKasi GoOgLE
}

\author{
${ }^{1}$ Syahtriatna Djusar, ${ }^{2}$ Taslim, ${ }^{3}$ Dafwen Toresa \\ 1,2 Universitas Lancang Kuning, Pekanbaru, Riau, Indonesia \\ email: ${ }^{1}$ eet@unilak.ac.id, ${ }^{2}$ taslim@unilak.ac.id, ${ }^{3}$ dafwen@unilak.ac.id
}

\begin{abstract}
Google site is a site that provides various services for various groups of users. Google Site Services are developing along with the development of user needs and the development of Information Technology. One of the services provided by Google Sites is a service in the field of education. Various services related to the world of education on the Google Site are: G Suite For Education, Classroom, Tasks, Chroombook, Google Cloud Platform, Virtual \& Augmented Reality and Jamboard. By utilizing applications on the Google Site, learning can be done online, so that if there are obstacles or obstacles in the face-to-face learning process caused by natural disasters, the learning process can still be carried out, where teachers and students do not have to be in one particular learning room. In general, the teachers at Pekanbaru 16 Public High School, have not used the google application in learning. The author will measure the variables that are suspected of influencing teachers not to use applications in learning. The method of this research is to determine the population, determine the variables and measure the relationship between variables with statistical equations and to use smartpls 3 applications for data processing. Based on the measurement results, it turns out the ease of use of the application variables, needs, abilities and interests, does not affect the perception of teachers to use the google application.

Keywords: Teacher, Google application, Learning, Perception, Smartpls
\end{abstract}

\begin{abstract}
Abstrak. Situs Google adalah sebuah situs yang menyediakan berbagai layanan untuk berbagai kelompok pemakai. Layanan Situs Google berkembang seiring dengan perkembangan kebutuhan user dan perkembangan Teknologi Informasi. Salah satu layanan yang diberikan oleh Situs Google adalah layanan di bidang pendidikan. Berbagai layanan yang terkait dengan dunia pendidikan yang ada di Situs Google adalah: G Suite For Education, Classroom, Tugas, Chroombook, Google Cloud Platform, Virtual \& Augmented Reality dan Jamboard. Dengan memanfaatkan aplikasi pada Situs Google, pembelajaran dapat dilakukan secara daring, sehingga apabila ada kendala atau hambatan pada proses pembelajaran tatap muka yang ditimbulkan oleh bencana alam, maka proses pembelajaran tetap dapat dilakukan, dimana guru dan siswa tidak harus berada di satu ruang belajar tertentu. Secara umum, para guru di SMAN 16 Kota Pekanbaru, belum memanfaatkan aplikasi google dalam pembelajaran. Penulis akan mengukur variabel-variabel yang diduga mempengaruhi guru untuk tidak menggunakan aplikasi dalam pembelajaran. Metode penelitian ini adalah dengan menetapkan populasi, menentukan variabel dan mengukur hubungan antara variabel dengan persamaan statistic dan memanfaatkan aplikasi smartpls 3 untuk pengolahan datanya. Berdasarkan hasil pengukuran, ternyata variabel kemudahan penggunaan aplikasi, kebutuhan, kamampuan dan minat, tidak mempengaruhi persepsi guru untuk menggunakan aplikasi google.
\end{abstract}

Kata Kunci: Teacher, Google Application, Learning, Perception, Smartpls

\section{Pendahuluan}

Menurut Undang-Undang Nomor 20 Tahun 2003 tentang Sistem
Pendidikan Nasional, pembelajaran adalah proses interaksi peserta didik dengan pendidik dan sumber belajar 
pada suatu lingkungan belajar. Pembelajaran semestinya dapat dilakukan dengan beberapa cara, diantaranya: tatap muka antara peserta didik dengan tenaga pendidikan dalam satu ruang tertentu, tatap muka antara peserta didik dan tenaga pendidik melalui perangkat teknologi informasi dengan tempat yang terpisah, pembelajaran tanpa tata muka di satu waktu yang sama ataupun pembelajaran tanpa tatap muka di waktu yang berbeda. Semua proses pembelajaran tersebut dapat dilaksanakan dengan pemanfaatan perangkat dan teknologi informasi.

Proses pembelajan di SMAN 16

Kota Pekanbaru yang biasanya dilakukan secara tatap muka antara peserta didik dengan tenaga pendidikan dalam satu ruang tertentu, kadang kala tidak dapat dilaksanakan. Hal ini disebabkan oleh beberapa faktor. Salah satunya adalah bencana kabut asap yang terjadi di kota Pekanbaru. Adanya kabut asap yang memberikan pengaruh tidak baik terhadap kesehatan, mengakibatkan proses pembelajaran di ruang kelas menjadi terhenti, karena sekolah diliburkan. Proses libur yang lama saat bencana kabut asap mengakibatkan terjadinya keterlambatan proses pembelajaran dan munculnya ketidaksesuaian dengan jadwal yang ada pada kelender akademik sekolah.

Untuk mengatasi hambatan proses pembelajaran tersebut, maka diperlukan sebuah terobosan solusi yang dapat dilakukan oleh guru dan mampu diikuti oleh siswa. Solusi yang diberikan harus sesuai dengan peraturan perundangan yang berlaku. Solusi yang dapat diberikan adalah proses pembelajaran jarak jauh dengan menggunakan perangkat teknologi informasi. Dalam pasal 31 ayat 1,2 dan 3 Undang-Undang Nomor 20 Tahun 2003 tentang Sistem Pendidikan Nasional, pendidikan jarak jauh dapat diselenggarakan pada semua jalur, jenjang, dan jenis pendidikan, pendidikan jarak jauh berfungsi memberikan layanan pendidikan kepada kelompok masyarakat yang tidak dapat mengikuti pendidikan secara tatap muka atau regular, pendidikan jarak jauh diselenggarakan dalam berbagai bentuk, modus, dan cakupan yang didukung oleh sarana dan layanan belajar serta sistem penilaian yang menjamin mutu lulusan sesuai dengan standar nasional pendidikan.

Untuk dapat melakukan pembelajaran jarak jauh, diperlukan keahlian dan keterampilan dari setiap guru untuk memanfaatkan teknologi informasi dalam melaksanakan pembelajaran jarak jauh. Saat ini untuk dapat melaksanakan pembelajaran jarak jauh, setiap guru tidak harus membangun aplikasi sendiri. Cukup banyak situs yang menyediakan aplikasi pembelajaran daring secara gratis. Saat ini guru pada SMAN 16 Kota Pekanbaru belum dapat memanfaatkan aplikasiaplikasi tersebut.

\section{Tujuan Penelitian}

Untuk itu, penulis ingin mengukur beberapa variabel yang di duga mempengaruhi persepsi guru, sehingga tidak memanfaatkan keberadaan aplikasi google dalam proses pembelajaran

\section{Tinjauan Pustaka}

Pada bagian ini akan dijelaskan tentang beberapa teori terkait yang menunjang penelitian.

Google Classroom, yaitu suatu serambi pembelajaran campuran yang diperuntukkan terhadap setiap ruang lingkup pendidikan yang dimaksudkan untuk menemukan jalan keluar atas kesulitan dalam membuat, membagikan dan menggolong-golongkan setiap penugasan tanpa kertas 
Situs web adalah sebagai kumpulan halaman-halaman yang digunakan untuk menampilkan informasi teks, gambar diam atau gerak, animasi, suara dan atau gabungan dari semuanya baik yang bersifat statis maupun dinamis yang membentuk satu rangka ian bangunan yang saling terkait dimana masing-masing dihubungkan dengan jaringan-jaringan halaman (Hyperlink).

"Persepsi adalah suatu proses dengan cara apa seseorang melakukan pemilihan, penerimaan, pengorganisasi, dan penginterpretasian atas informasi yang diterimanya dari lingkungan (Herlan dan Yono 2013)" . "Persepsi adalah proses dimana individu mengatur dan menginterpretasikan kesan-kesan sensoris mereka guna memberikan arti bagi lingkungan mereka (Robbins 2008). Persepsi seseorang itu ada yang merasa teknologi baru sangat bermanfaat terhadap aktivitasnya sehari hari. Tetapi ada juga persepsi seseorang yang menyatakan bahwa dengan adanya teknologi membuat dirinya tidak nyaman.

Persepsi seseorang terhadap minat seseorang dalam menggunakan teknologi dapat dikelompokkan sebagai berikut: Persepsi Kegunaan (Perceived Usefulness) merupakan keyakinan seseorang ketika menggunakan teknologi dapat memberikan manfaat dan hasil yang bagus, Persepsi Kemudahan (Perceived Ease Of Use) merupakan keyakinan seseorang ketika menggunakan suatu teknologi dapat dengan mudah digunakan dan dipahami sehingga pengguna tidak merasa berat ketika ada teknologi baru (Mulyana 2005).

Kemampuan pengguna menurut Stephen Robbins yang diterjemahkan oleh Diana Angelica, Ria Cahyani dan Abdul Risyid (2008:52), yaitu: "Kemampuan pengguna merupakan suatu kapasitas individu untuk mengerjakan berbagai tugas dalam suatu pekerjaan tertentu."

Minat, menurut Sondang $P$. Siagian (2002: 94) manusia sebagai pembeli produk pasti menggunakan berbagai pertimbangan dalam membeli atau tidak membeli suatu produk tertentu. Dapat disimpulkan Dengan adanya minat pada seseorang akan menunjukkan kecenderungan untuk memusatkan pada suatu objek yang menariknya pada dasarnya minat seseorang timbul karena pengaruh dari dalam dan luar dirinya yaitu lingkungan dimana individu berada.

\section{Hipotesis}

Hipotesis dari penelitian ini adalah sebagai berikut:

H1: Kemudahan penggunaan aplikasi memberikan pengaruh kepada minat H2: Kebutuhan terhadap aplikasi memberikan pengaruh kepada minat H3: Kemampuan penggunaan aplikasi memberikan pengaruh kepada minat H4: Kemudahan penggunaan aplikasi memberikan pengaruh kepada persepsi H5: Kebutuhan terhadap aplikasi memberikan pengaruh kepada persepsi H6: Kemampuan penggunaan aplikasi memberikan pengaruh kepada persepsi H7: Minat dalam menggunkan aplikasi memberikan pengaruh kepada persepsi H8: Kemudahan penggunaan aplikasi, Kebutuhan terhadap aplikasi dan Kemampuan penggunaan aplikasi, memberikan pengaruh kepada minat H9: Kemudahan penggunaan aplikasi, Kebutuhan terhadap aplikasi dan Kemampuan penggunaan aplikasi, memberikan pengaruh tidak langsung kepada persepsi.

\section{Metode}

Penelitian ini akan dilakukan dengan metode kuantitatif, yaitu data yang dikumpulkan berupa angka-angka. Penelitian kuantitatif adalah penelitian 
ilmiah yang sistematis terhadap bagianbagian dan fenomena serta hubunganhubungannya. Jumlah populasi dalam penelitian ini adalah 30 orang guru. Sampel diambil sebanyak 17 orang dari total seluruh populasi. Penelitian ini yang menjadi populasi adalah para guru di SMAN 16 Kota Pekanbaru. Sumber data dalam penelitian ini yaitu data primer. Pada penelitian ini, data diperoleh dari lapangan dengan menggunaka kuisioner. Instrumen penelitian yang digunakan adalah kuisioner (angket) yaitu daftar pertanyaan terstruktur dengan alternatif jawaban yang telah tersedia sehingga responden tinggal memilih jawaban sesuai dengan aspirasi, persepsi, sikap, keadaan atau pendapat pribadinya. Tingkat kebenaran dan kehandalan instrumen dapat diketahui dengan melakukan uji validitas dan uji reabilitas. Pengujian asumsi klasik menggunakan Uji normalitas, uji multikolinearitas, dan Uji heteroskedastisitas.

Metode Analisis Data di dalam penelitian ini terdapat dua metode analisis yang digunakan yaitu:

\section{Analisis Deskriptif}

Data yang telah dikumpulkan selanjutnya diolah dalam tabel, dan kemudian dibahas secara deskripif. Ukuran deskriptifnya adalah pemberian angka, baik dalam responden maupun dalam rangka presentase yang dituangkan dalam diagram atau tabel.

\section{Analisis Regresi Linier Berganda}

Bertujuan untuk mengetahui pengaruh variabel independen $(\mathrm{Xi} \ldots .$. $\mathrm{Xn}$ ) terhadap variabel dependen (Y).

\section{Uji Hipotesis}

Uji secara simultan "Untuk menguji pengaruh jenis variabel independen (X) terhadap variabel dependen $(\mathrm{Y})$.
Uji Secara Parsial Uji regresi parsial digunakan untuk mengetahui pengaruh dari variabel bebas (X) terhadap variabel terikat $(\mathrm{Y})$. Analisis ini digunakan untuk mengetahui variabel bebas yang paling berpengaruh diantara variabel yang lain.

\section{Hasil dan Pembahasan}

Pengabdian yang dilakukan meliputi tiga tahapan, dan setiap tahapan diikuti oleh 20 orang guru dari SMAN 16 Kota Pekanbaru dan masing-masing guru di minta untuk menjawab setiap pertanyaan, dimana setiap jawaban pertanyaan dalam bentuk skala liker, dengan kriteria: $1=$ Sangat Tidak Setuju; 2 = Tidak Setuju; $3=$ Setuju; 4 = Sangat Setuju.

Berikut ini adalah sepuluh butir pertanyaan yang diberikan kepada guru

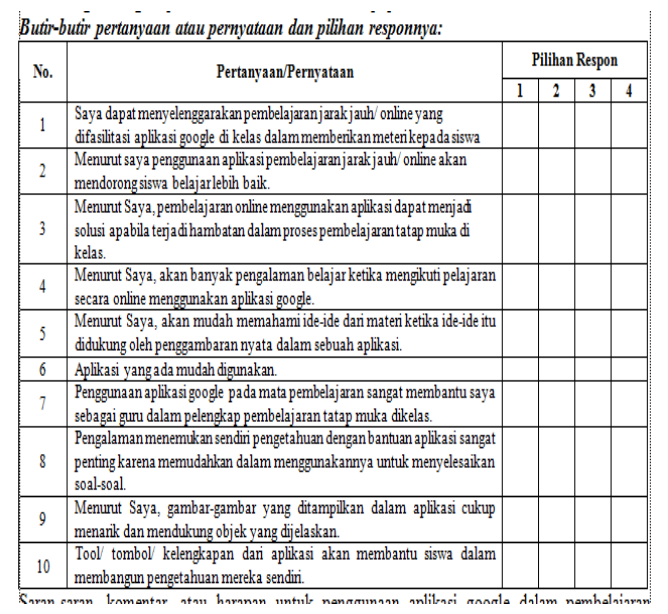

Gambar 3.1 Daftar Pertanyaan Guru 
Hasil jawaban 17 orang responden dari guru SMAN 16 Pekanbaru adalah sebagai berikut:



Gambar 3.2 Hasil Jawaban Guru

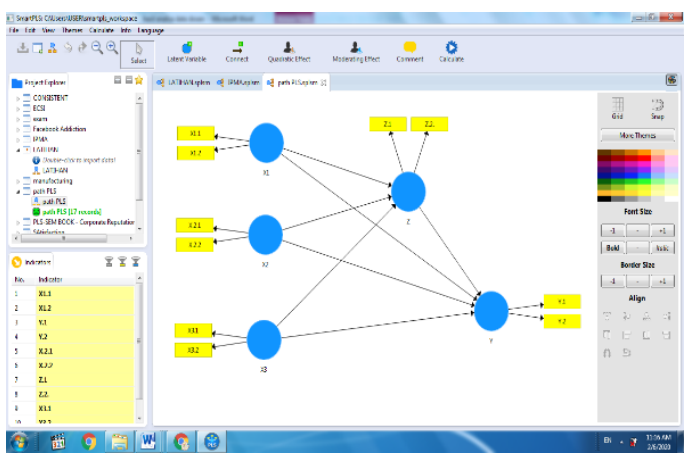

Gambar 3.1. Path PLS

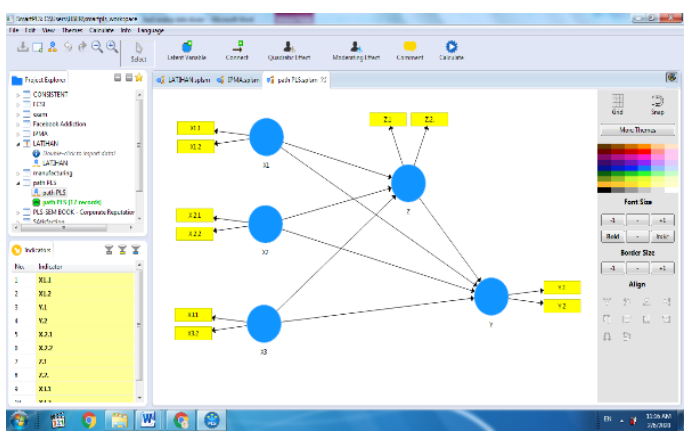

Gambar 3.2. Path Coefficients

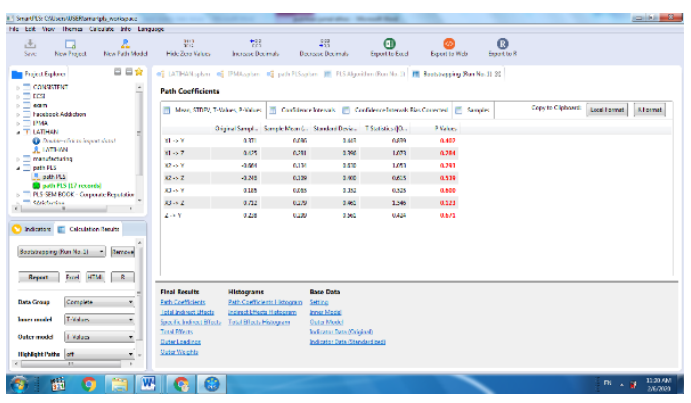

Gambar 3.3. Boot Strapping

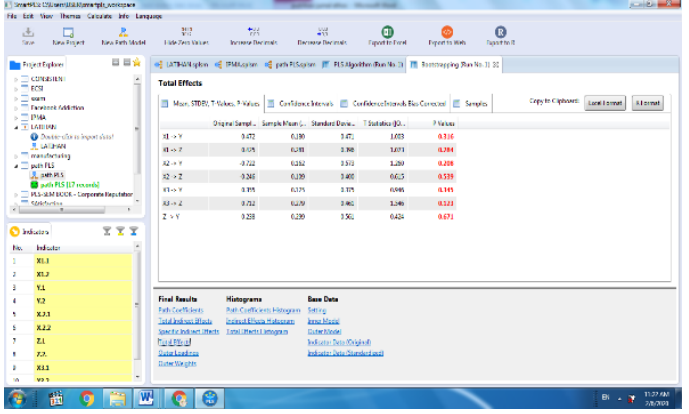

Gambar 3.4. Total Effect

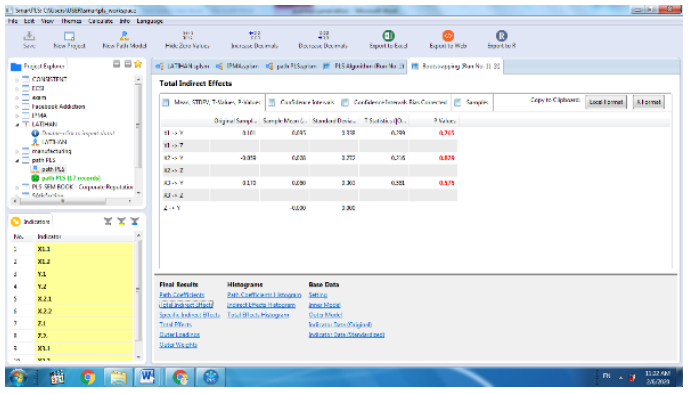

\section{Gambar 3.4. Total Indirect Effect}

\section{Kesimpulan dan Saran}

Tidak ada Hubungan antara kemudahan penggunaan aplikasi dengan minat. Tidak ada Hubungan antara kebutuhan aplikasi dengan minat. Tidak ada Hubungan antara kemampuan penggunaan aplikasi dengan minat. Tidak ada Hubungan antara kemudahan penggunaan aplikasi dengan persepsi. Tidak ada Hubungan antara kebutuhan aplikasi dengan persepsi. Tidak ada Hubungan kemampuan penggunaan aplikasi dengan persepsi. Tidak ada Hubungan antara minat penggunaan aplikasi dengan persepsi. Tidak ada Hubungan antara kemudahan penggunaan aplikasi dengan persepsi. Tidak ada Hubungan antara kemudahan penggunaan aplikasi, kebutuhan dan kemampuan dengan persepsi. Tidak ada Hubungan antara kemudahan penggunaan aplikasi dengan persepsi.

\section{DAFTAR PUSTAKA}

Deddy Mulyana, 2005, Ilmu Komunikasi: Suatu Pengantar, Bandung, Remaja Rosdakarya. 
Pendidikan, Menteri. Undang-undang Republik Indonesia Nomor 20 tahun 2003 Tentang Sistem Pendidikan

Nasional (2003).

Https://doi.org/10.16309/j.cnki.issn. 1007-1776.2003.03.004.

Robbins, S. 2008. Perilaku Organisasi, Jilid I dan II, alih bahasa : Hadyana Pujaatmaja. Jakarta: Prenhallindo.

Rosa A. S \& M. Shalahudin (2013). Rekayasa Perangkat Lunak. Bandung: Informatika.

Stephen P. Robbins and Timothy a. Judge. 2008. Perilaku Organisasi Edisi 12 buku 1. Terjemahan: Diana Angelica, Ria Cahyani dan Abdul Rosyid. Jakarta: Salemba Empat.

Siagian, Sondang P. 1994. Teori dan Praktik Kepemimpinan. Jakarta: PT. Rineka Cipta

Suherlan,Herlan MM \& Budiono, Yono MBA, MSC. 2013. Psikologi

Pelayanan. Bandung : Media Perubahan 